\title{
The Death of the Beautiful Deer (Smrt krásných srnců)
}

\author{
Author: Ota Pavel
}

First Published: 1971

Translations: German (Der Tod der schönen Rehböcke, 1973); Swedish (De vackra rådjurens död, 1974); Dutch (Karpers voor de Wehrmacht, 1976); Polish (Śmierć pięknych saren, 1978); Slovak (Smrt’ krásnych srncov, 1983); Japanese (Utsukushī shika no shi, 2000); Spanish (Carpas para la Wehrmacht, 2015).

Theatre Adaptations (in selection): Viola, Prague (1977, Povedený tatínek a já); Divadlo E.F. Buriana, Prague (1987, Můj tatínek a zlatí úhoři); Divadlo Rokoko, Prague (2008, Zlatí úhoři); Městské divadlo v Mostě, Most (2012, Povedený tatínek a my).

Film Adaptations: Kapři pro wehrmacht (the short story Carp for the Wehrmacht), short feature film; screenplay and film director Karel Smyczek, premiered 1975; Smrt krásných srnců (the short story The Death of the Beautiful Deer), short feature film; screenplay and film director Vladimír Merta; Zlatí úhoři (The Golden Eels), TV film; screen play Dušan Hamšík and Karel Kachyňa, film director Karel Kachyňa, premiered 1979; Smrt krásných srnců (literally The Death of the Beautiful Deer, in English as Forbidden Dreams), feature film; screenplay Dušan Hamšík and Karel Kachyňa, film director Karel Kachyňa, premiered 1987.

About the Author: Ota Pavel (1930-1973), originally Popper. His father Leo was a Czech Jew, his mother Hermína a Czech. Leo Popper was a commercial traveller. After the Nazi occupation, he lost his job and the family moved from Prague to the small town Buštěhrad near Kladno where Leo worked as a miner. Both of Ota's older brothers, Jiři (Jirka) and Hugo, were deported to Theresienstadt in February of 1943 and his father Leo in February of 1945. All three managed to survive. Ota's grandfather Ferdinand Popper died in a Jewish hospital during the war, his grandmother Malvína was killed in Auschwitz.

After the war, the whole family changed their surname from Popper to the Czech name Pavel. Ota worked as a sports journalist for magazines and Czechoslovak Radio. He accompanied the Prague football club Dukla on the way to the U. S. and other countries (the book of reports Dukla among the Skyscrapers). His literary tutor was Arnošt Lustig. In 1964, during the Olympic Winter Games in Innsbruck, Pavel had a nervous breakdown. From 1966 until his death, he received a pension for being disabled. In the beginning of his career, he published stories about Czech athletes. At the end of the 1960s, he started writing about his family's tales. These stories found great response and were often adapted for theatre, radio and film.

Ә Open Access. @ 2021 jiří Holý, Šárka Sladovníková, published by De Gruyter. (c))BY-Nc-ND This work is licensed under a Creative Commons Attribution-NonCommercial-NoDerivatives 4.0 License.

https://doi.org/10.1515/9783110671056-026 
Further Important Publications: Jak jsem potkal ryby (1974, posthumously, How I Met the Fish; short stories).

\section{Content and Interpretation}

In his collection The Death of the Beautiful Deer (as well as in How I Met the Fish), Ota Pavel describes his autobiographical experiences. The book is narrated in the firstperson, often from the perspective of Otik, a child and gradually becoming a young teen. He can be identified as the author himself, nevertheless some remarks and comments belong to the adult author in the time of the writing (similar to Grynberg's $\rightarrow$ The Jewish War, Dichter's $\rightarrow$ The God's Horse or Bořkovcová's $\rightarrow$ A Private Conversation). Moreover, the style includes some features of exaggeration and fairy tales. Therefore the stories oscillate between reality and fiction.

The first two stories recount the tale of the Popper family before the war. It is centred mainly on the narrator's father Leo, "a funny dad", a Jew who makes good business as a commercial traveller. However his greatest hobby is fishing in Nature and the whole family spends beautiful days near the Berounka river in Central Bohemia. Nevertheless, Otík's happy childhood "finished suddenly, because the former Private First Class Mr Adolf Hitler came with his moustache under his nose" (Pavel, 1991, p. 70). The stories The Death of the Beautiful Deer and Carp for the Wehrmacht (and also They Can Even Kill You in How I Met the Fish) depict the Nazi occupation and the restrictions of the Jews. The family has to move from Prague to the village. The father loses his job, his pond with carp is confiscated. Otík's brothers and father are sent to concentration camps and the young boy Otík nicknamed "Tushie" (Prdelka) stays alone with his mother and has to play the role of the head of the family.

However, his father shows great courage when he harvests fish from his former own pond to feed his family thereby risking his life. Later Leo removes his Jewish star and rides his bike to the Berounka river to bring food to his older sons who have been summoned for deportation. His friend, the ferryman Prošek, helps him by lending him a German Shepherd named Holan who can hunt deer. In the past, Leo Popper had fed Holan with sausages but now both of them, the man and the dog, are in a similar situation.

\footnotetext{
“Holan, now I'm a Jude, a Jew. I don't have any sausage. I'd need them for myself. I'm a Jew and I need meat for my wonderful boys. You have to get it for me!" [...] The eyes of the dog and the man met. Their eyes looked at each other for a long time, perhaps an eon. [...] and what they said to each other, no one will ever know because they are both dead. [...] Maybe they were griping about what it was like as a dog, or maybe as a Jew, but maybe all that doesn’t matter. (p. 75)
}

All members of the family manage to survive the war. The remaining short stories describe their life after it. The father and later Ota both became impassioned communists believing the socialist regime removes all racial prejudice and inequality between people. The story The Race through Prague (Běh Prahou, in English in Cross Currents, 1983) depicts this enthusiasm but also father's despair after the Slánský trial (1952). 
This was a great show trial against high-ranking Czechoslovak communists where their Jewish origin was stressed, in the spirit of Stalinist antisemitism. Ota's father paints over the red star on his front gate with the star of David. He "stopped being a communist and became a Jew again" (p. 142).

The Death of the Beautiful Deer contains alternately comic, idyllic and dramatic situations. It connects the naivety of the child's view with the nostalgia of the adult's perspective. The persecution of the Jews is presented in a few impressive scenes. For instance, in the scene where the dad has to bring the family's dog and the neighbour's cat to a Nazi office in Prague. Jews are not allowed to keep pets, and the animals will be probably killed.

\section{Main Topics and Film Adaptations}

In 1971 the book could only be published in censored form. The short story The Race through Prague was banned and also other "defective passages" criticising the socialist regime or mentioning the Jews were eliminated. The full and original edition of the author's manuscript was only possible in 1991, after the Velvet Revolution.

The character of Leo Popper is portrayed with some stereotypical Jewish attributes. He is an excellent businessman and bon vivant. On the other hand, he is also a Czech patriot and a brave man. During the war, he tries to protect his family, is not afraid of the Nazis (harvesting fish from the pond as well as hunting deer). After Leo leaves to Theresienstadt, little Otík imitates his father's courage by fishing illegally and exchanging carp for food necessary for him and his mother (in the short story They Can Even Kill You in the collection How I Met the Fish). Most ordinary Czech people help the Popper family in their hard life while the German Nazis are presented as rough people. The antisemitic behaviour of the Czechs appears only rarely.

Czech director Karel Kachyňa created two full length films based on Ota Pavel's stories. The first Golden Eels (1979) narrated from the perspective of Otík, an innocent child. The second Forbidden Dreams (1987) from more characters' points of view, nevertheless the father Leo is in the centre of the story. The persecution of the Jews and the Holocaust are almost a peripheral topic here. However, these short stories and films belong to the few works during so-called normalisation in Czechoslovakia in the 1970s and 1980s, which present the Jewish and Holocaust motifs.

\section{Cited Work}

Pavel, O. (1991). Zlatí úhoři, 3rd ed., ed. by B. Svozil. Praha: Československý spisovatel.

\section{Further References}

AS (= Stich, A.). (1976). K obecné češtině v současné krásné próze. Naše řeč, 58(4), pp. 215-223. Bolton, J. (2010). Czech literature. YIWO Encyclopedia of Jews in Eastern Europe. Available at: http://www.yivoencyclopedia.org/article.aspx/Czech_Literature [Accessed: 06.10.2019]. Jedličková, A. (1991). Ota Pavel: Smrt krásných srnců. In: Čes- 
ká literatura 1945-1970. Praha: SPN, pp. 411-422. Kaczorowski, A. (2018). Ota Pavel. Pod powierzchnia. Wołowiec: Wydawnictwo Czarne (in Czech extended 2020). Pavlová, V. (1993). Vzpomínky na Otu Pavla. Praha: Agentura V.P.K. Sladovníková, Š. (2016). Dětský pohled na holocaust. In: J. Holý, ed., Cizí i blízcí. Židé, literatura, kultura $v$ českých zemích ve 20. století. Praha: Akropolis, pp. 822-824. Sladovníková, Š. (2018). The Holocaust in Czechoslovak and Czech Feature Films. Stuttgart: ibidem, pp. 69-77. Svobodová, H. (1983). The Death of a Beautiful Fish. Cross Currents, 2(23), pp. 285290. Svozil, B. (2003). Krajiny života a tvorby Oty Pavla. Praha: Akropolis.

$\mathrm{JH}-\check{\mathrm{S} S}$ 